\title{
Engaging Political Islam: The Case of General Soeharto, Mahathir Mohamad, and Ferdinand E. Marcos
}

\author{
Elizar J. Zamora
}

\begin{abstract}
The effect of Islamic radicalism has been felt in many parts of the globe. Right after the 9/11 bombing of the World Trade Center in New York, there has been heightened anxieties about Islamic radicalism worldwide. In the light of this development Southeast Asian region has been dragged into the web of Islamic terrorism when in 2000 the Light Railway Train in Manila was bombed by Jemaah Islamiyah terrorists, and the tourist resort bombing in Bali, Indonesia in 2002. In 2001, Singapore's Internal Security Department classified intelligence reports reveal that Indonesia, Malaysia, southern Thailand, and southern Philippines were used as breeding and training grounds of terrorists. The extension of the U.S campaign against terrorism in the region has complicated the matter since American policy makers concentrated their efforts on the fringe violent Islamic extremist groups and portrayed them in western media as the sole representative of the Islamic world. This wrong assumption may lead to the demonization of Islam and definitely will have a big impact on the relations between the Muslim world and the west and among Muslim themselves. Thus, oftentimes there is a tendency to pigeon hole Islam, Islamic radicalism, Islamic fundamentalism, and political Islam as one. The paper demonstrates that the engagement of the three Southeast Asian authoritarian leaders: General Soeharto, Mahathir, and Marcos with political Islam proves that Islam in Southeast Asia is not monolithic that it is determined by context, it can be contained, co-opted, racialized, accommodated, and be used to legitimize power.
\end{abstract}

Index Terms - Islamic radicalism, Jemaah Islamiyah, Pan Islamic state, political Islam.

\section{INTRODUCTION}

Religious and ethnic identities are major irritants in the construction of national identity of almost all Southeast Asian post-colonial societies. The Islamic religion that gained a foothold in the region has been used by Muslims to demand the integration of Islam in the structuring of postcolonial secular society. In some places like Aceh in Indonesia, Patani in Thailand, and Mindanao in the Philippines, Islam has been used as a rallying cry for Muslim separatism. Like in the Middle East, Islam in Southeast Asia has served as a unifying factor and symbol of Muslims struggle against colonialism, authoritarian regimes, and global capitalism. The influx of new Islamic ideas to the region through long standing contacts with Mecca and Egypt as well as the rise of Islamic resurgence in the Middle East has a direct impact on the nature of Muslim struggle in Southeast Asia. The spread of political Islam in

Manuscript received June 19, 2018; revised September 11, 2018.

Elizar J. Zamora is with the Far Eastern University, Centro Escolar University, Manila, Philippines (e-mail: ezamora@feu.edu.ph). the region or the fusion of Islam in politics has the effect of creating stronger and wider bases of identity. The integration of nationalism on religion provides the most powerful sense of belonging to a community because it encompasses a wider and stronger political sphere. Islamic thinkers and writers realized that ties based on tribe, color, nation and race were considered to be ineffective [1]. In reinventing Islamic society, Islamists mobilized symbols, idioms, and Islamic narratives for political ends. In their political imagination, Islamists writers tried to revisit the past golden age of Islam and the high level of Islamic empire with the hope of forging a common abode of Islam (ummah). In political Islamist perspectives, the religious, legal and political spheres of society should not be separated [2]. Islam has to transcend national boundaries regardless of nationality and race to be identified with the east against the west. Culture is now to be seen via religion so that an attack against one Muslim is considered an attack against Islamic religion. However, the misleading image of political Islam as monolithic has blurred their vision in understanding Muslim society and politics and as well the problem posed by Islamic extremist. This image of political Islam has to be reconsidered since it is determined by the context within which they operate. There is a need therefore to have an adequate understanding and knowledge of political Islam as a religious, cultural and political phenomenon in order for their responses to be based on facts rather than unfounded fear. In this paper, the engagements of the three Southeast Asian leaders: General Soeharto of Indonesia, Mahathir Mohamad of Malaysia, and Ferdinand Marcos of the Philippines with political Islam will demonstrate that political Islam in Southeast Asia is not monolithic as perceived by many. The diversity of the Muslim world implies a diversity of methods employed by Islamists. What is true in Indonesia may not be true in Malaysia as the political Islam in each country is circumscribed by the colonial experience, socio-economic characteristics, political culture, and the border of individual state. In the same manner that the approaches employed by the three authoritarian leaders vary in their contestations with political Islam.

The study aimed to analyze the engagement of General Soeharto of Indonesia, Mahathir Mohamad of Malaysia, and Ferdinand Marcos of the Philippines with political Islam during their respective regimes. Specifically, the study sought answers to the following questions:

1) How did the following variables circumscribe political Islam's struggle against General, Soeharto, Mahathir Mohamad, and Ferdinand E. Marcos

1. 1 Social structure and demographic: factor

1. 2 Ethnic and cultural facto 


\section{3 The country's post-colonial: experience}

1. 4 Political structure of the country?

2) How did the three leaders respond to the challenge of Political Islam?

The study is anchored on the following assumptions that political Islam that spread in Southeast Asia is a multifarious phenomenon that takes on different expressions. Muslims of Southeast Asia were never monolithic. The contestations of General Soeharto, Mahathir, and Marcos with political Islam demonstrate that its perceived monolithic character fails to translate into reality. Islamists can be co-opted, racialized, adopt a divergent view, contests electoral process within the ground rules, and sometimes ethnically and geographically attached. That Islam can be wielded as an instrument of authority and legitimacy by the government as illustrated in the case of Mahathir Mohamad of Malaysia.

It is the hope that the research will have important contributions to the people of Southeast Asia. It has been quite some time that Islam as a religion has been politicized to advance political agenda through the use of violent struggle. As shown in the research, Islam or political Islam need not be violent or confrontational as demonstrated in the case of Indonesia and Malaysia. This research will also help widen the knowledge and understanding of Southeast Asians that political Islam in the region differs widely that of the Middle East, and Northern Africa. Member nations of the ASEAN (Association of Southeast Asian Nations) through their political and business leaders, policy makers including members of the diplomatic staff in foreign affairs and ministries and embassies who forge policies will also be benefitted by the research especially in dealing with the threat of Islamic radicalism.

The study specifically covered the regime of the three authoritarian leaders of Southeast Asia namely General Soeharto who served as the second president of Indonesia for 31 years after the ouster of President Sukarno in 1967 until his resignation in 1998, Mahathir Mohamad who served as the fourth Prime Minister of Malaysia from 1981 to 2003, and Ferdinand Marcos of the Philippines who served as the President of the Philippines from 1965 to 1986 , in their respective engagement with political Islam. The study limits only on the three authoritarian leaders of Southeast Asia in their respective engagement with political Islam for the reason that they were the only authoritarian leaders of the region whose regime contested the challenge of political Islam for a longer period of time. Moreover, the researcher believes that the contestations between Southeast Asian political Islam and the three authoritarian leaders under study will provide them some insights into the capabilities, strength, prospects, and weaknesses of political Islam. The engagement of General Soeharto with political Islam starts with the establishment of his New Order Regime in 1965 until his resignation in 1998. Mahathir Mohamad of Malaysia's engagement with political Islam started with his assumption as the Prime Minister to the time of his replacement in 2003 with a new prime minister. In the case of Ferdinand Marcos, the study will cover only the period when the Jabidah Massacre took place in 1968 as the most important spark that ignited the Moro separatist movement in Mindanao and Sulu to the period of his downfall in 1986.

\section{PRELIMINARY}

Southeast Asian region was put in spotlight when entangled in the wave of Islamic radicalism. After the September 11, 2001 terrorist attack on the World Trade Center, the Bali and Mariot Hotel Bombing Incidents in Indonesia, Southeast Asia is once again considered important in the United States of America's war on terror According to the Country Reports of the United States Bureau of Counter Terrorism and Violent Extremism Congress (2015), Malaysia was accused of cuddling Islamic terrorists and Indonesia the breeding ground of Islamic terrorist's cell. The Moro Islamic Liberation Front's military camps in Mindanao was reported to be used as training grounds by Islamic terrorists recruits connected to Osama bin Laden. The report has generated grave concern for the reason that it is of public knowledge that the Jemaah Islamiyah's long term goal is to establish a Pan- Islamic Southeast Asia which would be centered in Indonesia, and would include Malaysia, the Southern Philippines, Southern Thailand, and Brunei. The entanglement of the United States of America brought about by the extension of her campaign against terrorism in the region has complicated the matter since American policy makers concentrated their efforts on the fringe violent Islamic extremist groups and at the same time portrayed them in western media as the sole representative of the Islamic world. Thus, oftentimes there is a tendency to pigeon hole Islam, Islamic radicalism, Islamic fundamentalism, and political Islam as one. The danger therefore, is that the United States war on terrorism against a small minority group of Islamic terrorists maybe magnified to become later on as a war against all Muslims. As what the noted French Islamist Roy (1996) rightly said "The challenge of fundamentalist Islam is overrated". Too much preoccupation on radicalism and extremism has led them to ignore the important trend of liberal political Islam whose proponents value human rights and democracy, tolerance, and cooperation [3].

One basic question often asked about political Islam is that; is it monolithic? Or are Southeast Asian Muslims monolithic? Muslims or political Islam were used to be shown in many chronicles as people who stayed together, develop together, and fighting their enemies together [4]. The Islamic scholar John Esposito argued that Islamic movements cannot present a serious threat precisely due to their diverse and multifaceted nature. Despite the resurgence of Islam, Esposito dismisses the existence of an Islamic threat since most Islamic movements are not anti- Western, anti-American, or anti-democratic in nature [5]. Political Islam as a phenomenon is context-specific as shown in the differences of Islamists political imaginations as well as the actions and directions of its movements [6]. Political Islam is not a monolithic single movement or static. It is dynamic, shifting, changing and learning and most of all evolving. Moreover, political Islam is capable of evolving toward democracy and sometimes universal political values [7]. For instance, Islamic politics in Malaysia and Indonesia showed that in their struggle of instituting Islam as a national 
religion produced contrary results. In Malaysia the post colonial leadership instituted Islam as the official religion after gaining independence, whereas, in Indonesia the nationalist post-colonial leaders saw Islam as a threat to the unity of the Indonesian nation [8]. The non-monolithic nature of political Islam in Southeast Asia can also be seen in the manner of engagement against the secular state. In Indonesia moderate Islamists are committed to the political process and acceptable political means, while the conservative like the Nadhlatul Ulama (NU), Indonesia's oldest Muslim organization does not officially involve itself in politics [9]. A case in point showing the discord among the Indonesian Muslims is the Laskar Jihad's intervention on behalf of local Muslim and the escalation of communal violence in the Moluccas Island against the Christians. The radical Islamic group failed to mobilize Indonesian Muslims against their Christian enemies despite its claim to be fighting for their beleaguered minority Muslim brothers and for the Indonesian ummah [10]. Scholars of Indonesian politics are unanimous in their observation that: it is inconceivable why in a country with the largest Muslim population social agents of Islamic politics failed to contest state power effectively. As Lee (2004) puts it "Although Indonesia has the world's largest Muslim community, defeats of political Islam have far outnumbered victories" [11]. In Southeast Asian countries where Muslims are minorities and are fighting for secession from the secular state like Mindanao in the Philippines and Patani of Thailand, armed Muslim based separatist movements have engaged their respective government in a protracted and internecine struggle which is more vexing to the governments of the Philippines and Thailand. In his study on Muslim Separatism of Southern Philippines and Southern Thailand, Che Man noted one distinguishing difference between the Moro separatist movement in the Philippines to that of Patani separatist movement of Southern Thailand is that, the former was primarily led by traditional aristocratic and secular elite while the later was led mainly by religious elite which dominates the leadership [12]. Like in Indonesia where Islamic parties vary in their political platforms, two Malay Muslim political parties have their own conception of an Islamic state. The ruling political party coalition United Malay National Organization (UMNO), steadfastly claimed that Malaysia is indeed an Islamic state as defined in the fundamental law. The PanMalaysian Islamic Party (PMIP) on the other hand rejects UMNO's claim and argued that an Islamic state must fully implement Islamic laws in all realms including criminal laws [13].

\section{MethodolOGY}

The study is based on a qualitative research design which gives preference for holistic description of complex phenomena under study. The researcher employed the documentary analysis or content analysis method of which the document is a major part. Under this type of method the study of conditions at different periods of time may be made and the change and progress that took place between the periods may be noted or evaluated for any value it gives. As a research technique according to Fraenkel and Wallen
(2007) it enables researchers to study human behaviour in an indirect way through an analysis of their communications. Thus, laws, presidential decrees and proclamations, political speeches, agreements, declarations, manifestos, books, and articles containing any kind of communication can be analyzed.

For the purpose of the study the researcher utilized the documentary analysis or content analysis method of research and supplemented by interview of people who are knowledgeable and considered authority on the subject under study. The researcher interviewed the former Dean of Islamic Studies of the University of the Philippines, Dilliman Quezon City. Important documents were analyzed such as political speeches, presidential decrees, and issuances made by the three authoritarian leaders which has bearing with their contestations against political Islam. Important laws passed by the legislative bodies of Indonesia, Malaysia, and the Philippines designed to neutralize the forces of political Islamists were also analyzed demonstrating how the three leaders dealt with the challenged of political Islam. In the case of Indonesia the Indonesian Criminal Code, and the Anti-subversion Law, Soeharto's series of laws and regulations, intended to combat the growing strength of political Islam; like the Law on Mass Organizations, Law banning political parties that were based on religion, and as well as Soeharto's regulation which sought to manage religious education were also put into scrutiny. In the case of Mahathir Mohamad, an analysis of some of his select speeches, official statements, and declarations were made. His use of Islam to its nationalistcapitalist projects, intensified use of the Amended Internal Securities Act, Amended Societies Act, and censorship of the press were also analyzed. In the case of Ferdinand Marcos of the Philippines contestations with political Islam; the following important documents were also included and analyzed: Tripoli Agreement, Manifesto of the Moro National Liberation Front, Manifesto of the Muslim Independence Movement, Resolution No.18 of the Political Committee at the Fifth Islamic Conference of Foreign Ministers held at Kuala Lumpur on June 21- 25, 1974, and the Jeddah Accord dated January 3-4, 1987. Marcos's presidential decrees, letters of implementations, general orders which can be accessed and are readily available from the Official Gazette of the Republic of the Philippines at www. Gov.Ph. were also included.

Variables that Circumscribed Political Islam's Struggle against General Soeharto, Mahathir Mohamad, and Ferdinand Marcos

The engagement of political Islamists against the three authoritarian leaders under study can be better understood by examining how the different variables constricted their contestations. Variables intrinsic and extrinsic of Islamism affected political Islamists contestations since it has been capitalized by the three authoritarian leaders against them. More so that these variables produced varied responses from Soeharto, Mahathir, and Marcos.

\section{A. The Social Structure and Demographic Variable}

The Islamic religion that spread in Southeast Asia has to contend with the pre-Islamic doctrines and animistic beliefs long practiced by indigenous people. The incorporation of 
these pre-Islamic doctrines made Southeast Asian Islamic religion unique. Southeast Asian Islam has been characterized as non-aggressive flexible creed that enabled its believers to retain their traditional ways [14]. The Indonesian Muslims for example are categorized as moderate or their practice is syncretic Islam. The division of Indonesian Muslims into santri and abangan and as well as other forces of aliran illustrates a variety of religious expressions. Santri, or pious Muslims generally represents political Islam, on the other hand abangan or nominal Muslims are identified with secular politics and absorb cultural influence from priyayi traditions, like pre- Islamic, Javanese-Hindu customs and supernatural beliefs. Aliran forces dictate how Islam is interpreted and practiced from group to group and region to region. Social scientists argued that the formation of a superior Islamic identity in Indonesia is undermined outright at the lower level since loyalty is given to the group first. It is for these reasons that Islamic revolution is unlikely to rise or led the role in Indonesian political life [15]. The divisions among Muslim groups created a cleavage in which General Soeharto capitalized to fend off Islamists challenges. Another reason that delimits political Islam's aspiration for a single Islamic vision is the mobilization of Indonesia's diverse quarter billion population. Indonesia's archipelagic framework which stretches as wide as the United States accounts for linguistic ethnic, and social heterogeneity which continuous to undermines social cohesion and national unity. Indonesia's 17,000 islands explain why despite the fact that 85 percent of her population is nominally Muslims,' yet, the varieties of beliefs suggest more of diversity than unity.

Like Indonesia, Malaysia's racial diversity has spawned a lot of problems in recent decades for social cohesion. Over half of the population is of Malay descent which forms about 55 percent, the Chinese formed about a quarter of the population estimated at 25 percent, 7 percent the Indians and the Indigenous people combined form about 11 percent. This explains why social grouping based on ethnic affiliation in Malaysia is so strong that the ruling coalition government starting from the time of Prime Minister Tunku Abdul Rahman has to deal with in balancing the contrariety of interest among the various racial and indigenous groups in order to remain in power. The Malays or bumiputera (sons of the soil) were predominantly rural and agricultural whose lives remains stagnant were left behind in economic development as compared to the Chinese and the Indians. Thus, the founding fathers of the nation have to secure and empower them in the newly independent state by enshrining and defining in the constitution that "Malays are Muslims who practice Malay customs and culture." The Federal constitution also accords special privileges to Malays by adopting Malay as the official language and Islam as the official religion which in several instances caused racial tensions and animosities. The Dayaks, Iban, and Orang Asli of Borneo who constitute the indigenous communities remain in the periphery of Malaysian politics and economy.

The Muslims are the biggest cultural minority in a Christian dominated Philippines. In southern Philippines, the groupings of people are as follows: Christian majority, Muslim minority, tribal minority, and lumadnons. Despite being the largest cultural minority group the Muslims are in turn subdivided into three major sub groups: the Maranaos are clustered in Lanao provinces, Maguindanao in Cotabato area, and Tausug in Sulu Island of the south constitutes 75 percent of the Moro population. The Tausug Muslims of Sulu are often characterized as formidable fighters, aggressive and devoutly Islamic. They consider themselves superior to the Samals, Badjaos, Molbogs and Yakans. The Tausug's feeling of superiority is illustrated in an oft quoted observation that a Tausug may marry a Samal girl, but rarely did a Tausug girl marry down to a Samal. Another major Muslim group are the Maranaos of Lanao who are known to have astute business acumen. The Maguindanaons of Cotabato on the other hand are said to be highly skilled in land holdings and are more inclined to white collar jobs [16]. The geographic, linguistic, and cultural isolation account for Muslims of Mindanao and Sulu disunity and at times rivalry. Philippine history attests that Islam failed to eradicate the disunity and rivalry among separate Muslim groups contrary to the claims of Islamic writers. The Muslim scholar, Samuel K. Tan conceded that Islam nominally binds Muslims to their belief since the only unifying tendency was found in the micro levels. The nuclear cohesion brought about by kinship ties which spring from the datus's autocratic power and resources should not be magnified to be the unity that galvanized Muslim ethnic groups in the Philippines [17]. The concept of dar-ul-Islam or abode of Islam which identifies Muslim from non-Muslim does not correspond with an identity of Islamic or Moro nationalism. In fact Cotabato Muslims never call themselves as Moros despite long appeals to Morohood by Muslim separatists [18]. The Moro wars fought by the Muslims against the colonizers which lasted for more than a hundred years were accentuated by betrayal by one sultan or datu against another or if not in collaboration with the colonizers to obtain political favors. Muslim rajahs and datus even engaged in dynastic wars over the control of the Pulangi River as illustrated in the case of Sirungan the Rajah of Buayan against Buisan the Datu of Maguindanao even if they were relatives [19]. It is the same disunity that handicapped the Muslim separatist movement in the 70's against Ferdinand Marcos.

\section{B. The Ethnic and Cultural Variables}

Ethnic pluralism exists in both mainland and maritime Southeast Asia. Multi-ethnic division refers to a society that has many different ethnic groups within their common social identity. The existence of minority communities has posed various concerns like acceptance within the larger society, assimilation of autonomous people, and diminution of the sphere of local authority under the policy of unification. The archipelagic framework of Indonesia accounts for its religiously and ethnically fragmented society. Major ethnic groups include: Atchenese, Bataks, Menangkabaus, Javanese, Sundanese, Madurese, Balinese, Buginese, Dayaks, and Papuans and a hundred of minor ones inhabit the country's 17,000 islands. The country's motto "Bhenika Tunggal Ika" translated as "we are many but one" or unity through diversity reflects the various problems beneath the social cohesion that it portrays. Despite the fact that Indonesia is a Muslim majority country, yet only 85 percent of the country's population is nominally 
Muslim. Since its introduction in the $15^{\text {th }}$ century to Indonesia, Islam has already undergone several modifications in so far as its religious beliefs and practice is concerned. Thus, religious division exist as devout Muslim who advocated a purified Islam is called santri as distinguish from nominal Muslims known as abangan. Santri identifies themselves with Islamic organizations and Islam for them is of prime importance. Abangan and santri Muslim looks each other with contempt as the former considers the latter as fanatics while santri considers abangan as rich, stingy, sanctimonious "Arabs", ignorant in religious practice and had little interest in them [20]. These strands of Islamic expressions are only a few of a thousand that exist in Indonesia which produces wide gaps among Muslims in Indonesia. Linguistic, religious, ethnic, and social heterogeneity are often the cause of religious and sectarian classes in various parts of the country.

The insular condition of the Philippines produced multiethnic divisions and rivalries that political Islamists have to contend with. The introduction of a new sect Sufis in the $12^{\text {th }}$ century to maritime Southeast Asia including southern Philippines who infused mystical versions of Islam claiming supernatural powers has the effects of undermining Islam's homogenizing influence to Southeast Asian Muslims. The ethno-cultural factor that circumscribed political Islam in Southeast Asia is illustrated in the case of the Moro secessionist movement in Muslim Mindanao Philippines. One major handicapped that greatly affected the secessionist struggle was the serious rivalries emanating from the ethnocultural differences among the Tausug, Maguindanaons, and Maranao Muslims. History attests that not even the more than three centuries of Moro Wars against Spanish colonizers forged an overall alliance among the major Muslim societies [21]. At the height of the separatist struggle the composition of the MNLF drifted only towards the Tausug ethnic group. The question of who should led the movement, represent and receive international financial and material support from generous Islamic donor countries continues all throughout without being resolved. The astute Ferdinand Marcos was quick in capitalizing the divisions within the Muslim secessionist ranks by co-optation and accommodation of some Muslim leaders through patronage.

On the other hand, Malaysia's multi-ethnic society has also been the cause of ethno- religious divisions that threaten the ruling coalition government of Mahathir Mohammad. According to Kadayifci and Orellana (2009) ethno-religious conflict is one where conflicting groups define themselves along ethno-religious lines, religious identity can create sharp distinctions between parties, and create group mobilization. The state sponsored Islamization program of the government was designed to outsmart the Islamist opposition rival in order to win the Muslim vote to keep the coalition government afloat. Like in Indonesia, the Muslim political leaders of Malaysia have already realized long before independence that due to its multi-ethnic composition it should never become an Islamic state. Otherwise, according to the former Malaysian Prime Minister Tunku Abdul Rahman, it would violate the understanding held in trusts with the largely non-Muslim Chinese and Indian communities. The failure of the dominant Malay opposition party PAS (Parti Islam Se-
Malaysia or Pan-Malaysian Islamic Party) to get the upper hand in fighting for an Islamic constitution for Malaysia and its avowed conversion to an Islamic state is axiomatic of political Islam's inability to forge Muslims to a common cause.

\section{Indonesia, Malaysia, and the Philippine's Post- Colonial Experience}

Southeast Asia's post-colonial experience develops from and mainly refers to the time after colonialism. As a postmodern discourse it has been resorted to as an approach to culture and identity from the vantage point of the colonized and the colonial powers. Southeast Asia's post-colonial experience was characterized by an aggressive drive in structuring the nature of each independent state. The process of social engineering varies from state to state. In a multiethnic society where ethnic differences abounds reaching a compromise and consensus was difficult. At times, the process of state building was a contentious one. Contending social forces wanted to impose their own ideology and visions to be the basis of the body politic. In the Indonesian post-colonial experience the different forces that formed part of the nationalist struggle against the Dutch made use of the said historic triumphant experience as basis of their contention in the post-colonial politics. These forces include the Indonesian Army, the Communists, and the "extreme right" (Islamic forces) as powerful contenders for state power. Sukarno knew that the unity of the fragile Indonesian nation was in constant threat of disintegration if Islamic forces will prevail. In a tactical move to counter Islamists forces he allied himself with the Communists. However, the aborted coup of September 20, 1965 resulted to the destruction of the Communists Party and as well as the downfall of Sukarno. General Soeharto with the backing of the military became the undisputed leader of Indonesia and the Armed Forces (Angkatan Bersenjata Republik Indonesia or $A B R I$ ), especially the army assumed dominant role within the state and society. Since the defeat of the Communist was done by the army in collaboration with the Islamic organizations in concert, Islamic leaders began to feel that Islam was the most important civil force in society. They thought that Islam will be given a special place in the nation's character. It is in this context that Indonesian Islamists forces demands from the secular state and as well as General Soeharto's attitude in dealing with those demands can be properly understood. From the very beginning the army has been suspicious of Islam since it has spawned three Islamic rebellions in post-war Indonesia. From the army's perspectives Islam was synonymous to revolt and opposition to secular state. Injecting religion into politics will weaken the ideal of Indonesian nationalism that the army stood for. Moreover, Islamic forces are seen through the lenses of the army as too exclusivists and intolerant to unite the nation, and that their overriding concern with religion disqualifies them as serious proponents of rapid modernization [22]. The Javanese generals who controlled the army were apprehensive that the ideal of harmony which is so basic in Javanese culture was in danger. General Soeharto's New Order Regime was determined to sideline its remaining powerful potential enemy by sticking to the Pancasila of Sukarno as the 
official ideology of the state. The Islamic threat was invented and emphasized, since there was a need to protect the fragile Indonesian unity and integrity.

The Malaysian post-colonial society inherited the serious ethnic division produced by colonial policies. Despite repeated attempts made by the coalition government in improving the lot of the Malay Muslims by adopting a series of New Economic Programs the social pyramid remains as is. The Malay Muslims that constituted the majority of the population remained marginalized. The largest Islamic party United Malays National Organization (UMNO), as the dominant political party of the ruling coalition was hard pressed to improve the lot of the Malay Muslims as its dominance was always challenged by rival Islamist political parties (Parti Islam Se-Malaysia PAS) that promised the Bumiputera an Islamic State. The Youth Islamic Movement (ABIM) on the hand blamed the government for the growing secularization of the state and as well as the loosening of morals among Malaysians. The constant claim of the PAS that Malaysia is not an Islamic state but rather a secular one appeals to many Muslims electorate as reflected in its favourable showing at the polls. Thus, the UMNO led government was forced to adopt a stronger Islamic stance to belie the accusations of the PAS and the Islamic Youth Movement. With the ascension of Mahathir Mohamad as the new Prime Minister of Malaysia in 1982, he immediately launched the policy of Islamization and the inculcation of the Islamic values in government [23]. It is the persistence of ethnic division and as well as the marginalization of majority Malay Muslims in the postcolonial and independent Malaysia that Mahathir's engagement with political Islam was affected. Mahathir like his previous predecessors was aware that an exclusivist Islam has no place in a multi-ethnic Malaysia. His state sponsored Islamization of Malaysia was well calculated to allay fears of the non-Muslim population and at the same time to pose as the true representative of Islam.

The Muslim struggle dates back during the Spanish and American colonialism and later against the Philippine Republic and continued even to the present. The Muslims first fought against the Spanish colonizers who wanted to integrate them to the Spanish colonial government. When the Philippines was ceded to the United States of America by virtue of the Treaty of Paris, again the Muslims fought the Western colonizers who considered them as a threat to their religion and ways of life. The Muslims continued to fight against being integrated into the newly born Philippine Republic as it is tantamount to the loss of their identity, and besides they never considered themselves Filipinos. Muslim animosities against the Christian government of Manila were compounded when the latter started to resettle landless $H u k$ rebels to Mindanao as a way of solving the agrarian problem of Luzon. The resettlement program of the government to Mindanao spawned mass migration of landless Christians to the point of encroaching upon their homeland and worse marginalizing them. The subsequent exploitation of Mindanao by the government in collaboration with affluent Christian private enterprises led to the loss of Muslim lands. The failure of the government to work for a meaningful integration of the Moros to Philippine society and as well as decades of neglect serves as the underlying cause behind the Muslim unrest that spawned separatist movement during the Marcos era. The unrest coincided with the increasing Islamic consciousness among Muslims brought about by contacts with Arab and Egyptian Muslim scholars. Muslim grievances were sometimes accompanied by religious coloration in order to mobilize Islamic sentiment behind their cause. Ferdinand Marcos' engagement with political Islam was a continuation of a century's old struggle of the Moros extended during his time.

\section{The Political Structure of Indonesia, Malaysia, and the Philippines}

A better understanding of the engagement of General Soeharto, Mahathir Mohamad, and Ferdinand Marcos with political Islam necessitates an examination of the political structure of Indonesia, Malaysia, and as well as that of the Muslim societies of Mindanao and Sulu. Political structure refers to institutions or groups and their relations to each other as well as their pattern of interaction within the political system. It provides a better view of the political landscape serving as platform in understanding the dynamic of a political entity. The dichotomy within Muslim community into santri and abanqan is extended and strongly felt in the Indonesian political landscape. Abangan Muslims lean towards secular politics while santri or pious Muslims represents political Islam. The Javanese aristocracy priyayi who are nominal Muslims and of which traditionally the political leaders of the country came were suspicious and distrustful of the forces of Islam. Thus, the Indonesian army officers who belong to the Javanese cultural tradition which placed a high value on order, harmony, and calmness looked at Islam as a discordant voice and a threat to the integrity of the fragile Indonesian society [22]. General Soeharto who belonged to priyayi and abangan tradition was determined to demobilize Islam by continually supporting the Pancasila as the national ideology of Indonesia and at the same time co-opting Islamic groups and political parties to support his New Order regime. Islam in Indonesia is socially contested and that political Islam as well animates Indonesian politics. The concept of political Islam introduced in Southeast Asia is a new phenomenon and that it needed much time to have its roots firmly establish [24]. Indonesian elections are replete with examples demonstrating why Muslim political parties continue to fail to dominate the polls. In the first democratic experiment in 1950 Masyumi which represented Islamic interest and was considered the largest Islamic party failed to dominate the polls. Masyumi gained only 49 seats out of the 232 member unicameral parliament (Dewan Perwakilan Rakyat, People's Representative Council). Masyumi's failure to dominate the polls was attributed to the party's internal division between the Orthodox and the Modernist religious leaders which in 1952 resulted to a split. The Islamic party's unity was further undermined when Nahdlatul Ulama another major Islamic political party left Masyumi to form a separate political party. It is for this reason that coalition with other Muslim parties has been a mainstay in Indonesian Islamic politics.

Malaysia's geography is one reason for its society's racial diversity. Malaysia consists of the Peninsula in mainland 
Southeast Asia at the southern part of Thailand, Sabah and Sarawak on the island of Borneo. Communalism is too strong as every government legislation is strongly contested and has to consider the interest of 55 percent Malays of the country, 25 percent Chinese, 7 percent Indian, and the smaller minority groups. The Malays are Sunni Muslim and are predominantly rural and agricultural. Sons of the soil or (Bumiputera) as they were known originally lagged behind economically as compared to their Chinese and Hindu brothers who controlled the economy respectively. Concessions were made by the government of then Tunku Abdul Rahman to uplift the conditions of the Bumiputera which later caused tensions and animosities among the Chinese and the Hindus who felt being discriminated. This social tension erupted in the worst racial riots that the country experienced in 1969 which costs the lives of more than two thousand. Divisions within the Malay Muslim can also be seen as expressed in the platforms of Islamic political parties. The Parti Islam Se-Malaysia (PAS) the strongest Islamic party in Malaysia advanced conservative Malay Muslim interest and continues to be real threat of the dominant United Malay National Organization. Moderate Islamic party on the other hand do not subscribe to the call for the creation of an Islamic state. It is within this context that the leaders of the United Malay National Organization ruling coalition government starting from Tungku Abdul Rahman, Abdul Razak, and Mahathir Mohamad has to take into consideration in balancing the interest of the various contending forces of society. Mahathir has to racialize Islam in order to get the support of the majority of the Malay Muslim and to pre-empt the Parti Islam Se Malaysia (PAS) from threatening UMNO's core communal support. Mahathir's used of the resources of the government in order to sideline Islamists forces that threatened social harmony was with the imprimatur of the ruling UMNO ruling coalition government. The adoption of the state ideology of Rukunegara, consisting of five principles: belief in God, loyalty to king and nation, upholding the constitution, rule of law, and good ethics was designed to safeguard the unity of the nation [25].

The Bangsamoro people or Muslim communities share a common historical tradition, religious affinity and culture. History attests that prior to Western colonialism Muslim communities were already politically organized as shown in the existence of sultanates, kingdoms and principalities. The fragmented nature of Muslim society and as well as the nature of its kinship system has the effect of polarizing loyalties and interest along bloodlines. In the Moro society the sultans and datus belonged to the aristocratic class and were considered the most dominant in the social hierarchy for they commanded the loyalty and service of the commoners for them [26]. Muslims viewed their sultans and datu as representing an institution of Islam and interpret the government's refusal to recognize its authority as rejection of their religion. As regards political structure of Moro, Mednick characterized it as pyramidally arranged hierarchy of political authority [27]. At the apex was the sultan or Raja (ruler), serving as the head of state from whom authority was derived. Next to the sultan is the panglima or (sultan's personal representatives), who serve as the chief administrator of a district or political unit. The sultan also occupies the highest position in the religious hierarchy of the Moro society as the religious head. The qadi or (judge) is the one who serves as the sultan's religious supervisor and chief authority in matters of Islamic law (sharia). The pendita a man well-versed in the Quran and the works of the Prophet Muhammad serves as adviser to the panglima in the district level. Other religious functionaries are the imam (head of the Mosque), Khatib or preacher, and bilal or (prayer caller). The Moro social and political structures are similar but not identical. According to the Malaysian scholar Che Man not all Moro groups had sultans and the number of sultanates varies [12]. Each sultanate has each own claim of sovereignty to their respective territory which causes sometimes rivalry and animosities. As in the colonial period these sultanates were not always united in fighting against the colonizers. T. G. S. George in his work noted that the institution of datus as it developed in Mindanao was a major obstacle to national integration and as well to Muslim progress [28]. This social cleavage of the Moro society has given Ferdinand Marcos in his fight against the Moro separatist movement a breathing space to choose from a lot of options at his disposal.

The responses of the three authoritarian leaders under study against political Islam vary as they appropriated state power at their disposal. As shown in the tables below (Table 1, Table II, and Table III) General Soeharto, Mahathir Mohamad, and Ferdinand Marcos' ultimate goal was the containment of political Islam. The variety of their respective contestations shed another dimension for better understanding of the nature of Southeast Asian political Islam.

From the very start, General Soeharto's military backed regime has been suspicious of any organized group that will undermine his New Order Regime. Soeharto's political moves were usually aimed at depolitization and demobilization of any political party and group interest in the guise of political stability and unity. Muslim mass organizations which have always harboured political ambitions and a potential threat to his regime, were the object of his crafty manipulation. In a move to neutralize political Islam, Soeharto in 1973 ordered the fusion of all four Muslim political parties into one single party, the United Development Party (Partai Perasatuan Pembangunan or PPP). The fusion of all Muslim parties had the effect of undermining the coherence of individual component parties [29]. Moreover, the continued intervention of the government in the internal affairs of the component parties through cooptation and accommodation rendered the parties ineffectual. To further emasculate Islamic parties, the government in 1984 passed the Law on Mass Organization. Under the said law, political parties that wanted to participate in the national elections were required to subscribe to the ideology of Pancasila and were prohibited to organize between elections [30]. In effect the law systematically deprive all political parties to promote their platforms of government and limited their ability to draw support from their constituencies. The move was an attempt of the New Order regime to eliminate any chance for pro-Islamic groups to promote Islamic ideology in the country [31]. Thus, in a nutshell it is tantamount to an absence of organized Muslim opposition against the 
government. Another masterful stroke of General Soeharto in demobilizing Islam was his adoption of several strategies designed to weaken the very foundation of Islam's constituency which includes the mosques, preachers, intellectuals, Ulamas (Muslim religious scholars), and women's associations. In the 1970's through the initiative of the government state-chartered organizations were established like the Indonesian Council of Ulama (MUI), Indonesian Dakwa Council (MDI), and the Indonesian Mosque Council (DMI). In 1996 the Indonesian Coordinating Body of Muslim Preachers (BAKUMUBIN) was also established. These organizations later on joined the Golkar (Political party of General Soeharto) umbrella organizations like the Islamic Commission Forum for Mass Organizations and were linked to government departments. Through this scheme, the regime was able to divert the activities of these organizations away from independent political concerns and ultimately in support of the Soeharto regime. Through it the New Order Regime also was able to deny the Muhammadiya the leading Islamic modernist socio-economic organization from the support of its own organizations. It is in this context that for two decades General Soeharto was able to neutralize the political aspirations of Islamic political parties and organizations.

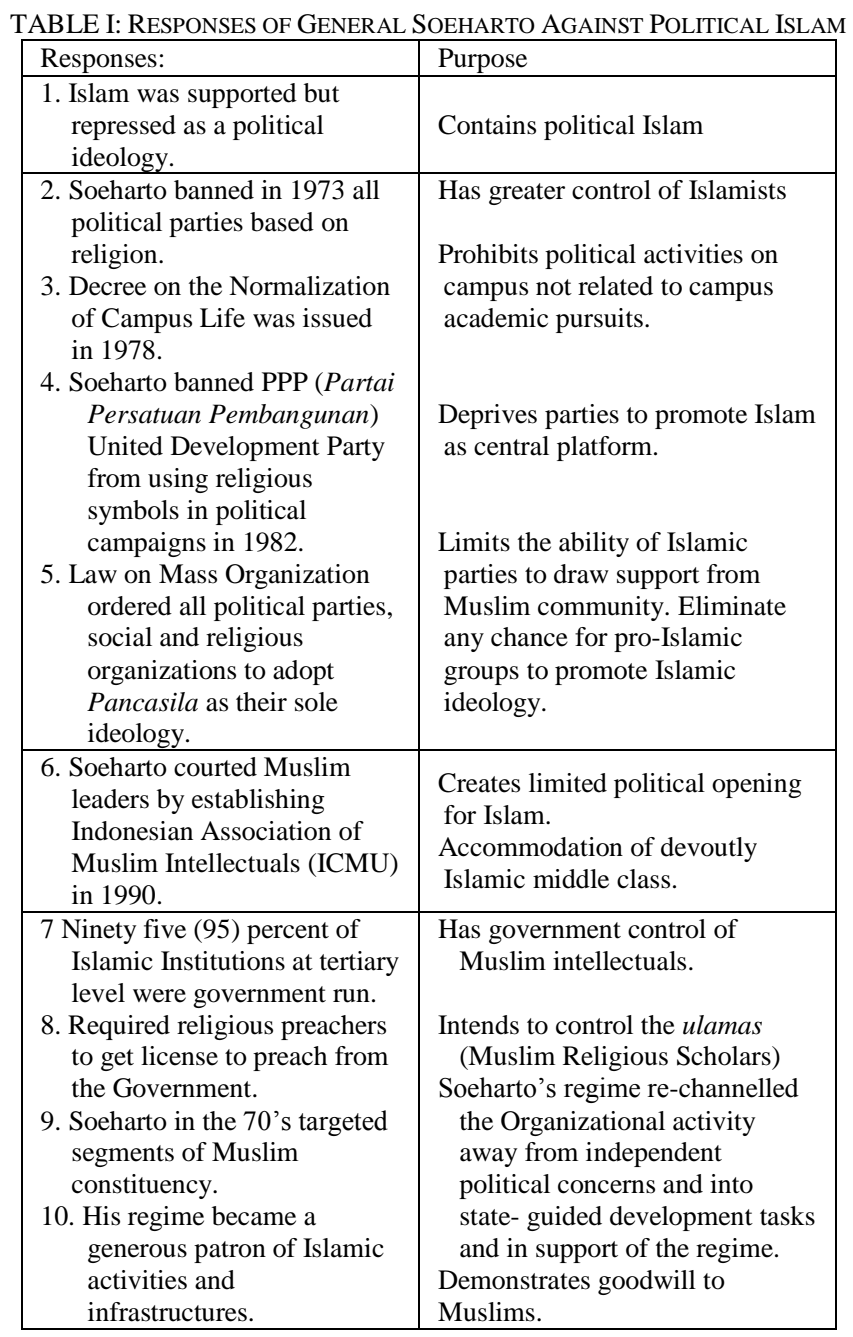

TABLE II: RESPONSES OF MAHATHIR MOHAMAD AGAINST POLITICAL

\begin{tabular}{|c|l|c|}
\hline Responses & \multicolumn{1}{|c|}{ Purpose } \\
\hline $\begin{array}{c}\text { 1. Mahathir co-opted Islam and } \\
\text { wielded it as an instrument }\end{array}$ & $\begin{array}{l}\text { To undermine the PAS and } \\
\text { ABIM's politicking. }\end{array}$ \\
\hline
\end{tabular}

\begin{tabular}{|c|c|}
\hline of authority. & \\
\hline $\begin{array}{l}\text { 2. The State has been an } \\
\text { Islamizing state. }\end{array}$ & $\begin{array}{l}\text { To gain support of the Muslim } \\
\text { Malays. }\end{array}$ \\
\hline $\begin{array}{l}\text { 3. Mahathir helped create the } \\
\text { preconditions for Malaysian } \\
\text { Islam to emerge as a force } \\
\text { for democracy, pluralism } \\
\text { and a more open society. }\end{array}$ & $\begin{array}{l}\text { To undermine PAS and ABIM's } \\
\text { politicking. }\end{array}$ \\
\hline $\begin{array}{l}\text { 4. Mahathir reinvented and } \\
\text { redefined Islam. He Used } \\
\text { Islam to its nationalist- } \\
\text { capitalist projects. } \\
\text { 4.1 The international Islamic }\end{array}$ & $\begin{array}{l}\text { To respond to the spread of Islamic } \\
\text { resurgence and to out Islamize the } \\
\text { opposition } \\
\text { PAS (Islamic Party of Malaysia). }\end{array}$ \\
\hline $\begin{array}{l}\text { University in Kuala Lumpur } \\
\text { was launched in } 19782 .\end{array}$ & $\begin{array}{l}\text { To produce an Islamic- minded } \\
\text { constituency. }\end{array}$ \\
\hline $\begin{array}{l}\text { 5. Mahathir in } 2002 \text { declared } \\
\text { that Malaysia was already an } \\
\text { Islamic state. } \\
\end{array}$ & $\begin{array}{l}\text { To undercut political Islamists } \\
\text { religious politicking. }\end{array}$ \\
\hline $\begin{array}{l}\text { 6. Almost all mosques come } \\
\text { under government control. } \\
\text { 6.1 Mosque officials are } \\
\text { appointed by government } \\
\text { Religious Department. }\end{array}$ & To contain political Islamists. \\
\hline $\begin{array}{l}\text { 7. Government amended the } \\
\text { Internal Securities Act, and the } \\
\text { Parliament passed in } 1981 \text { the } \\
\text { Amended Societies Act. }\end{array}$ & $\begin{array}{l}\text { To prohibit any society to } \\
\text { challenge any matter on the } \\
\text { Monarchy, Islam, national } \\
\text { language and special rights of } \\
\text { Malays. }\end{array}$ \\
\hline $\begin{array}{l}\text { 8. Bermana government } \\
\text { controlled agency becomes the } \\
\text { sole distributor of foreign news } \\
\text { as of May } 1,1984 \text {. } \\
8.1 \text { The passage of the } \\
\text { Amended Printing Presses and } \\
\text { Publication Act of } 1984 \text {. }\end{array}$ & $\begin{array}{l}\text { To tighten regulations affecting } \\
\text { freedom of the press. } \\
\text { To empower the Home Minister } \\
\text { absolute discretion to grant, revoke } \\
\text { or suspend publishing and printing } \\
\text { permits both foreign and local. }\end{array}$ \\
\hline
\end{tabular}

Mahathir Mohamad's contestations to the challenges posed by political Islam is said to be unique in the sense that he used Islam as an instrument of authority and legitimacy of his coalition government. The proliferation of the dakwah (Muslim revivalist groups) that calls for Islamic fundamentalism, promoting rigid codes of conduct, and the implementation of the Islamic law drove the Mahathir ruling coalition government in adopting the "state directed Islamization of Malaysia" approach. Mahathir reinvented and at the same time redefined Islam to forge Malay unity. He demonstrated that Islam can be compatible with the process of modern nation building despite the fact that Islam was constitutionally instituted as the official religion in order to protect the hegemonic position of the Muslim Malays. Mahathir's Islam is one which endorses and enables economic development in pursuit of government's objectives. It is an Islam which disciplines and controls by defining as "deviant" those groups and individuals who threatened, even by being different [32].

Ferdinand Marcos response to the secessionist problem was full-scale military operations, and at the same time cooptation of the Muslim elite leaders who were willing to cooperate. Cognizant of the rivalries and dissention among Muslim leaders Marcos was quick to capitalize it to his advantage. He knew for a fact that many Muslim groups were not in conformity with the concept of secession and as well as the violence of the campaign. There were traditional Muslim leaders who were the beneficiary or self-appointed conduit of state resources intended for the benefit of their locality, but do not have the stamina to endure in a protracted armed struggle. The cleavage within the secessionist group was manifested when the Bangsa Moro Liberation Organization (BMLO) leaders: Rashid Lukman, 
Macapanton Abbas, Gibril Ridha, and Napis Bidin when failed to secure assistance from Libya agreed to co-operate with the Marcos government. They insisted that equal status with Misuari be accorded to them by the government and as well as by the powerful foreign benefactors. Misuari's steadfast position in claiming to be the only representative of the Moro people finally shattered the unity of MNLF leaders. Rashid Lukman and Macapanton Abbas group accused the Misuari group of betrayal and counter revolution. The group decided to change their previous stand from independence to autonomy. To further create divisions within the Moro leadership, Marcos accorded Rashid Lukman as the paramount Sultan of Mindanao and Sulu. The Muslim Aristocratic elite's collaboration with Marcos was dictated by the fact that they began to see the difficulty of winning over the Moro struggle which had definitely moved along radical lines [33]. Marcos continued courting the support of the aristocratic Muslim elite in his campaign against the Moro struggle by giving them government positions both in national and local legislative bodies. Rebel returnees who belonged to datu families were granted logging concessions, export licenses and high government positions in the regional autonomous government [34].

TABLE III: RESPONSES OF FERDINAND MARCOS AGAINST POLITICAL

\begin{tabular}{|c|c|}
\hline \multicolumn{2}{|c|}{ ISLAM } \\
\hline Responses & Purpose \\
\hline $\begin{array}{l}\text { 1. Marcos rejected Muslim } \\
\text { Independence and insisted } \\
\text { autonomy instead. }\end{array}$ & $\begin{array}{l}\text { To serve as important barrier to } \\
\text { the Muslim separatist struggle. }\end{array}$ \\
\hline $\begin{array}{l}\text { 2. Full-scale military operations } \\
\text { and deployment of more } \\
\text { troops and military resources } \\
\text { to Southern Philippines }\end{array}$ & $\begin{array}{l}\text { To neutralize the Moro } \\
\text { rebellion. }\end{array}$ \\
\hline $\begin{array}{l}\text { 3. Marcos took advantage of the } \\
\text { movement's factionalized } \\
\text { and ethno-cultural splits. }\end{array}$ & $\begin{array}{l}\text { To divide and weaken the } \\
\text { secessionist movement. }\end{array}$ \\
\hline $\begin{array}{l}\text { 4. Marcos launched } \\
\text { Reconstruction and } \\
\text { Development Programs for } \\
\text { Mindanao. } \\
\text { 4.1 The Philippine Amana Bank } \\
\text { was created. } \\
\text { 4.2 Marcos issued Presidential } \\
\text { Decree No. } 93 \text { in } 1973 \\
\text { legalizing smuggling in Sulu } \\
\text { Sea. } \\
\text { 4. } 3 \text { Marcos issued Letter of } \\
\text { Instruction 1-A in } 1973 \\
\text { authorizing the use of Arabic } \\
\text { as a medium of instruction in } \\
\text { madaris schools. } \\
\text { 4. } 4 \text { Proclamation } 1198 \text { of } 1973 \\
\text { declared Muslim holidays as } \\
\text { legal Philippine Holidays. } \\
\text { 4.5 Letter of Instruction - } 82 \text { of } \\
\text { 1973 created the Institute of } \\
\text { Islamic Studies. }\end{array}$ & $\begin{array}{l}\text { To repair the damage brought } \\
\text { by the armed conflict and } \\
\text { consolidated existing } \\
\text { rehabilitation programmes. } \\
\text { To meet the banking, credit, and } \\
\text { financial needs of Muslims. }\end{array}$ \\
\hline $\begin{array}{l}\text { 5. Muslim laws were codified } \\
\text { and Sharia Courts were } \\
\text { created. }\end{array}$ & $\begin{array}{l}\text { To integrate strategies to } \\
\text { incorporate some aspects of } \\
\text { Islamic law }\end{array}$ \\
\hline $\begin{array}{l}\text { 6. Marcos succeeded in insisting } \\
\text { that the government will take } \\
\text { all constitutional means to } \\
\text { implement the Tripoli } \\
\text { Agreement. }\end{array}$ & $\begin{array}{l}\text { To give Marcos a breathing } \\
\text { space to undermine the } \\
\text { agreement. }\end{array}$ \\
\hline
\end{tabular}

The internationalization of the Bangsa Moro struggle was a momentary triumph for Nur Misuari for in 1974, the powerful and influential Organization of the Islamic Conference (OIC) intervened on behalf of the MNLF, and in 1976 Marcos was hard pressed to sign the Tripoli Agreement, in Libya. Not to be outdone Marcos insisted that his proposed provision that: "The Government of the Philippines shall take all necessary constitutional process for the implementation of the entire Agreement" be included in the final draft and indeed, becomes paragraph 16 of the Tripoli Agreement [35]. The Tripoli Agreement which provided autonomy to 13 provinces of southern Philippines was astutely undermined by Ferdinand Marcos. Marcos a brilliant lawyer knew that the autonomy for the region was subject to the approval of the Mindanao Christians who constitute about 77 percent of the population of the region. $\mathrm{He}$ insisted on holding a plebiscite to determine what provinces would become part of the autonomous region. The result of the plebiscite reveals that 95 percent of the region rejected the creation of autonomous region. Thus, when the plebiscite produced the result he expected, Marcos implemented the Agreement as he chose [36]. On the other hand, in order to blunt the Moro secessionist struggle, Marcos embarked socio-economic development strategies. He therefore issued series of decrees, orders, proclamations, and letters of instructions designed to put an end to the conflict.

To repair the damage brought about by the armed conflict, the government organized the Rehabilitation and Development for Mindanao (RAD). Corolarily Marcos created Presidential Task Force for the Reconstruction and Development of Mindanao (PTF-RDM) the purpose of which was to assess the damage on private property, mobilization of funds and preparation of an integrated program of full reconstruction, and restoration of peace and order. Another socio-economic strategy undertaken was: creation of the Philippine Amana Bank intended to meet the banking, credit, and financial requirements of Muslims. The bank was also designed to help Muslim pilgrims to save for the haj (pilgrimage to Mecca). Muslim laws were codified and Sharia Courts were created in Autonomous government Regions IX-XII.

\section{CONCLUSIONS}

The social structure of Indonesia circumscribed political Islam's struggle against General Soeharto, since it created divisions among Muslim groups which has the effect of undermining plans for the establishment of a superior Islamic identity. Indonesia's diverse quarter billion population continues to undermine Islamic social cohesion. That Malaysia's major contending social forces delimits whatever plans for an Islamic state since the Mahathir government has to make a balancing act in order to preserve social cohesion. On the other hand the fragmented nature of Muslim society in southern Philippines as well as the nature of its kinship system has the effect of polarizing loyalties and interest along bloodlines.

Malaysia's multi-ethnic society begets ethno-religious division that threaten the ruling coalition government of Mahathir and even among Muslim Malays varied 
interpretations of Quranic precepts. In the case of the Muslims of southern Philippines, ethno-cultural differences among the Tausug, Maguindanaons, and Maranao Muslims produced serious rivalries that weakened the secessionist movement.

The Army (Angkatan Bersenjata Republik Indonesia$A B R I$ ) having played a major role in the nationalist struggle considered the Islamic forces as a threat to the integrity of the newly born republic. In the case of Malaysian postcolonial society, it inherited the serious ethnic division produced by colonial policies. Thus, despite Mahathir's series of New Economic Programs the social pyramid remains as is. It is the persistence of ethnic division and as well as the marginalization of the Malay Muslims that Mahathir's engagement with political Islam was affected.

Ferdinand Marcos engagement with political Islam was a continuation of a century's old struggle of the Moros extended during his time. Long years of neglect and marginalization compounded the Muslims grievances which exploded into a separatist rebellion.

The division within Indonesian Muslim community into santri and abangan is extended in the Indonesian political landscape. The Javanese aristocracy priyayi who are nominal Muslims were suspicious and distrustful of the forces of Islam. The multi-racial framework of Malaysia where Muslim Malays lagged behind economically as compared to the Chinese and Indians caused tensions and animosities when the government tries to uplift the conditions of the former. The institution of sultan and datus who belonged to the aristocratic class in the Moro political structure was a major obstacle to the Bangsamoro separatist movement.

That General Soeharto's responses to the challenge of political Islam effectively kept political Islamists at bay. With the military at his back, he cunningly supported Islam but repressed it as a political ideology. That Mahathir Mohamad by protecting the hegemonic position of the Malay and by the use of the apparatus of the state, his political Islamists critics failed to dissuade Muslim Malays to their cause. Ferdinand Marcos initial response to the Moro problem using the military option proved to be ineffective, but later gained the upper hand by cooptation of Muslim elite and by able diplomacy deprived the MNLF of Arab countries support.

The contestations of General Soeharto, Mahathir Mohamad, and Ferdinand Marcos with political Islam vary, yet it resulted to the same favourable result: the containment of political Islam.

\section{REFERENCES}

[1] N. Altuntaş, "Religious nationalism in a new era: A perspective from political Islam," African and Asian Studies, vol. 9, pp. 420-424, 2010.

[2] O. Roy, The Failure of Political Islam, Cambridge: Harvard University Press, 1996, p. 13.

[3] G. Fuller, The Future of Political Islam, New York: Palgrave, 2003, pp. $54-55$.

[4] T. G. S. George, Revolt in Mindanao: The Rise of Islam in Philippine Politics, Kuala Lumpur: Oxford University Press, 1980, p. 22.

[5] J. Esposito, The Islamic Threat: Myth or Reality, New York: Oxford University Press, 1992, pp. 200-212.

[6] M. Ayoob, "Political Islam: Image and reality," World Policy Journal, pp. 1-2, 2004.

[7] G. Fuller, "The future of political Islam," Foreign Affairs, vol. 81, no. 2, pp. 48-60, 2002.
[8] K. Hamayutso, "Islam and nation building in Southeast Asia: Malaysia and Indonesia in comparative perspective," Pacific Affairs, vol. 75 , no. 3, pp. 354-355, 2002.

[9] R. A. Asi and J. C. Liow, "Political Islam in Southeast Asia: One Ummah, many narratives," Technology in Asia, vol. 9, no. 2, pp. 5354. 2008.

[10] M. Davis, "Laskar Jihad and the political position of conservative Islam in Indonesia." Contemporary Southeast Asia, vol. 24, pp. 21-23, 2002.

[11] J. Lee, "The failure of political Islam in Indonesia," Stanford Journal of East Asian Affairs, vol. 4, no. 1, p. 86, 2004.

[12] K. W. Man, Muslim Separatism: the Moros of Southern Philippines and the Malays of Southern Thailand, Singapore and New York: Oxford University Press, pp. 17-18, 1990.

[13] I. A. Bakar, "The theories of Islamic state as advocated by the two Malay political parties in Malaysia," The Interdesciplinary Social Sciences, vol. 6, no. 1.pp. 94-99, 2011.

[14] T. G. S. George, Revolt in Mindanao: The Rise of Islam in Philippine Politics, Kuala Lumpur: Oxford University Press, 1980, pp. 25.

[15] R. Dayley and C. D. Neher, Southeast Asia in the New International Era. Central Avenue, Boulder: Westview Press, 2013, pp. 240-241.

[16] T. G. S. George, Revolt in Mindanao: The Rise of Islam in Philippine Politics, Kuala Lumpur: Oxford University Press, 1980, pp. 22-23.

[17] S. K. Tan, "Unity and disunity in the Muslim struggle," Asian Studies, vol. 11, no.3, pp. 133-134, 1973 .

[18] T. M. McKenna, "Appreciating Islam in the Muslim Philippines authority, experience, and identity in Cotabato," in Islam in An Era of Nation-States Politics and Religious Renewal in Muslim Southeast Asia, R. W. Hefner and P. Horvatich Ed. Honolulu: University of Hawaii Press, 1997, pp. 46-47.

[19] C. A. Majul, Muslims in the Philippines, Quezon City: The University of the Philippine Press, 2009, pp. 38-39.

[20] D. P. Chandler and R. R. William, In Search of Southeast Asia A Modern History, Honolulu: University of Hawaii Press, 1987, pp. 300-301.

[21] N. M. Saleeby, The Moro Problem, Manila: Bureau of Printing, 1913, pp. $15-18$.

[22] A. A. Samson, "Army and Islam in Indonesia," Pacific Affairs, vol. 44, no. 4, pp. $545-565,1971$

[23] B. W. Andaya and L. Y. Andaya, A History of Malaysia, Houndmills, Basingstoke, Hampshire: Palgrave, 2001, pp. 331-333.

[24] J. M. Wadi, "Former dean of the University of the Philippines institute of Islamic studies," Personal Interview, vol. 18, January 2017.

[25] D. S. Desai, Southeast Asia Past and Present, Boulder Colorado: Westview Press, 2013, p. 288.

[26] P. G. Gowing, The Muslim Filipinos: Heritage and Horizon, Quezon City: New Day Publishers, 1979, p. 52.

[27] M. Mednick, "Some problems of Moro history and political organization," Philippine Sociological Review, vol. 5, no.1, pp. 43-46, January 1957.

[28] T. G. S. George, Revolt in Mindanao: The Rise of Islam in Philippine Politics, Kuala Lumpur: Oxford University Press, 1980, p.98.

[29] R. W. Liddle, "Soeharto's Indonesia: Personal rule and political institutions," Pacific Affairs, vol. 58, no. 1, p. 76, 1985.

[30] L. Suryadinata, Election and Politics in Indonesia, Singapore: Institute of Southeast Asian Studies, 2002, p. 33.

[31] R. W. Hefner, "Islamization and democratization in Indonesia." in Islam in An Era of Nation-States: Politics and Religious Renewal in Muslim SoutheastAsia, R. W. Hefner and P. Horvatich, Ed. Honolulu: University of Hawaii Press, 1997, p. 88.

[32] P. Martinez, "Mahathir, Islam, and the New Malay Dilemma," in Mahathir's Administration Performance and Crisis in Governance, $\mathrm{H}$. K. Leong and J. Chin Ed. Singapore: Times Editions, 2003, pp. 238239

[33] S. K. Tan, The Internationalization of the Bangsa Moro Struggle. Diliman, Quezon City: Center for Integrative and Development Studies, University of the Philippines, 1993, pp. 43-44.

[34] T. M. Kenna, Muslim Rulers and Rebels: Everyday Politics and Armed Separatism in the Southern Philippines, Berkeley: University of California Press, 1998, pp. 163-167.

[35] M. D. Vitug and G. M. Gloria, Under the Crescent Moon: Rebellion in Mindanao, Quezon City: Ateneo Center for Social \& Public Affairs, 2000, pp. 34-35.

[36] L. G. Noble, "The Moro national liberation front in the Philippines," Pacific Affairs, vol. 49, no. 3, 1976. 


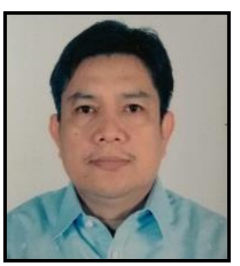

Elizar J. Zamora was born in Amlam, Negros Oriental, Philippines. He is a candidate for $\mathrm{Ph}$. D. in Southeast Asian Studies at Centro Escolar University, Manila. He is a holder of bachelor of arts degree major in political science from Foundation University, Dumaguete City, Philippines. He finished his bachelor of laws degree from the University of the East, Manila. Prof. Elizar J. Zamora earned his master of arts in history at Ateneo De Manila University, Philippines. He is at present an associate professor at Far Eastern University Department of
Political Science and History, Institute of Arts and Sciences, Manila, Philippines. He handled Philippine history and culture, ancient and medieval political theories, and government and politics of Southeast Asia subjects respectively. He was a paper presenter at the Fourth International Conference of the International Council for Historical and Cultural Cooperation-Southeast Asia and the 2017 Philippine Historical Association Annual Conference held at De La Salle University, Manila last September 15, 2017. He is an active member of the American Studies Association of the Philippines. 